\title{
Outside Directors, Corporate Governance and Firm Performance: Empirical Evidence from India
}

\author{
Naveen Kumar \\ Research Scholar (Corresponding author) \\ Department of Management Studies, \\ Indian Institute of Technology Roorkee, \\ Uttarakhand, 247667, India \\ E-mail: naveensrivastav@gmail.com \\ J. P. Singh \\ Professor, Department of Management Studies, \\ Indian Institute of Technology, Roorkee, \\ Uttarakhand, 247667, India
}

Received: May 3, 2012

Accepted: June 27, 2012

Published: December 1, 2012

doi:10.5296/ajfa.v4i2.1737

URL: http://dx.doi.org/10.5296/ajfa.v4i2.1737

\begin{abstract}
The current study examines the efficacy of outside directors on the corporate boards of 157 non-financial Indian companies for the year 2008. The research particularly investigates if the monitoring by grey director (non-executive non-independent) and independent director influences firm performance. Research finding reveals that while the proportion of grey directors on board has marginally deteriorated effect, the independent director's proportion has an insignificant positive effect on firm value. Outcome of research has significant implications for devising a board model for companies in India that have a significant ownership concentration and insider control. Independent directors require greater representation on the board in lieu of other non-executive outside directors.
\end{abstract}

Keywords: Outside directors, Independent directors, Corporate governance, Firm performance, Insider ownership 


\section{Introduction}

Corporate governance has become vital issue all around the world, particularly, in the aftermath of global financial crisis that teetered many economies into recession. Much of the recent discussion that has taken place centers on an effective corporate governance mechanism to protect shareholder rights and their wealth. The corporate governance is an important issue of public policy debate in India because of ongoing discussions within government and various regulatory bodies to promulgate the new Companies Act. Efficacy of sound corporate governance mechanisms in India and its regulation cannot be overemphasized, understanding the fact that investors and shareholders lost around 2.8 US billion dollars in country's largest accounting fraud at Satyam Computers Limited (Tellis, 2009). Further, external corporate governance mechanism and market forces are weak in Indian capital market. Therefore, it is essential to enforce proper corporate governance structure through law. Assuring good corporate governance in companies through outside directors is a prominent public policy issue in India.

Boards comprising of outside directors monitor corporate management on the behalf of shareholders (Fama and Jensen, 1983). In the agency settings of emerging economies, where ownership concentration is the general norm along with weak protection of shareholder rights, composition of board with outside directors (particularly independent directors) pose a significant challenge. As such, supervision of the management by outside directors cannot be overemphasized. Further, the board performs multifaceted tasks (Ruigrok et al., 2006) and has direct or indirect effect on firm performance. Therefore, the pertinent issue worthy of consideration is board composition with outside directors (independent and grey directors) under concentrated ownership, optimal from the perspective of maximizing shareholder value.

The current study aims to enhance our understanding about various theoretical foundations on outside directors as an important corporate governance mechanism and their effect on firm in different institutional settings. The primary objective of paper is to investigate how the arrangement of outside directors affects the corporate performance of Indian companies. Our second objective is to propose and validate various theoretical hypotheses with the moderating effect of insider ownership and control on outside director performance. The empirical outcome of this study will help to determine the effectiveness of outside directors in the presence of dominant shareholders. It will help regulators and policy makers to determine board composition in India.

\section{Related Literature}

Corporate board is considered as the zenith of internal corporate governance mechanism (Brennan, 2006). Board of directors on behalf of shareholders is envisaged with the role of monitoring the management and protecting their rights (Jensen and Mecking, 1976). The monitoring by the board is important because potential cost is incurred when management may pursue its own interest at the expense of shareholders' interest (Hillman and Dalziel, 2003). In order to reduce the agency cost, arising from the separation of ownership and control in developed countries, the board is required to compose of a majority of outside 
directors. Board independence is considered crucial because outside directors considered as true monitors' and can discipline the management and improve firm performance (Fama and Jensen, 1983; Weishbach, 1988; Duchin et al., 2010). Outside directors being financially independent of management, free from potentially conflicting situations able to alleviate agency problems and curb managerial self-interest (Rhodes et al., 2000). They can protect the shareholder interest, perform monitoring and control function in a better way to align firm resources for better performance.

There have been several efforts to find empirical evidence on the effectiveness outside director on firm performance. The results, however, have been diverse. While several authors find that independent outside directors, protect shareholders in specific instances in which there is an agency problem (Weishbach 1988; Byrd and Hickman, 1992; Xie et al., 2003; McCabe and Nowark, 2008). Several researchers have found a positive relationship with the presence of outside director and firm performance. Daily and Dalton (1992), Baysinger and Butler (1985) and Brickley et al. (1994) find more independent directors on the board improve economic performance of the firm. Several other studies find a positive impact from appointing outside independent directors upon the board. Studies find less likelihood of financial statement fraud (Beasley , 1996), positive price reaction (Rosenstein and Wyatt , 1990 ), positive reaction to tender offer bids and poison pill adoptions (Byrd and Hickman, 1992; Brickley et al.,1994), better firm profitability ( Ezzamel and Watson, 1993) and better stock price returns ( Bhagat and Black, 1999) in relation to outside and independent directors.

Several other empirical studies, however find either no significant effect or negative effect of outside directors on firm performance. Many researchers (Baysinger and Butler, 1985; Dalton et al., 1998; Dalton and Daily, 1999; Fernandes, 2005) do not find any relationship between board composition with representation of outside independent directors and firm performance. Hermalin and Weishbach (1991), Meharan (1995), Bathala and Rao (1995), Vafeas and Theodoru (1998), Core et al. (1999), and Klien (1998) and Yermack (1996) report an insignificant relation between corporate board independence and various measures of firm performance. Many researchers also have reported a negative relationship between the proportion of outside directors and firm value. Agrawal and Knoeber (1996) and Bhagat and Black (2002), finds a negative relationship between the proportion of outside directors on board and firm performance. Efficacy of outside directors as governance mechanism is therefore questionable in the developed counties because of presence external governance mechanism like mergers and acquisition, market for corporate control and product market competition.

Efficacious corporate governance mechanisms of the developed countries may not be effective in emerging markets and other countries due to its ownership structure and strength of the capital market. Apart from few Anglo-Saxon countries, most of the companies of other countries exhibit high ownership concentration (Shleifer and Vishny, 1997; La Porta et al., 2000; Claessens et al., 2000). The typical agency problem, which arises from the separation of ownership from control in such a setting, is between the dominant shareholder and other minority shareholders. Dominant shareholders have the ability (because they control the firm 
with sufficiently high voting rights) and the incentive (because usually their cash flow rights are much lower than their voting rights) to expropriate other shareholders by diverting the firm's resources to themselves (Claessens et al., 2002; La Porta et al., 2002). The pertinent question under case is whether board composition with a majority of independent directors will increase firm value by assuring the investors and minority shareholders that an independent board will prevent diversion of firm resources and better monitoring (Dhaya et al., 2007). Choi et al. (2007) in Korean context finds that effect of independent directors on firm performance is strongly positive, while contributions from grey director is ambiguous. Dahya et al. (2007) in their analysis of 799 firms across 22 countries find a significant positive relationship proportion of independent directors and firm performance in the presence of dominant shareholders and countries with weak protection of shareholder rights. Further, their results also find a negative relationship between the higher proportion of independent directors on board and related party transactions. Erickson et al. (2005) in dominant shareholder regime for Canadian companies find a negative relationship between the fraction of outside directors and firm value. However, the authors suggest that independent board was able to mitigate agency problem arising out of dual class common stock. Ehikioya (2009) and Uadiale (2010) for Nigerian companies find the positive association proportion of outside directors and firm performance. Ameer et al. (2010) for Malaysian companies suggest independent directors perform better than affiliated (grey) directors. Yammeesri and Herath (2010) for Thailand companies and Rashid et al. (2010) for companies in Bangladesh report a positive but an insignificant relationship with presence of independent directors and firm value.

\section{Outside Directors and Corporate Governance in Indian Context - Hypothesis Development}

India, like many other emerging Asian countries has high ownership concentration, with dominance of family controlled firms along with many state controlled firms being a peculiarity of the corporate sector (Chakrabarti, 2005). Many companies are affiliated with a family managed business group, and show high ownership concentration with the dominant (promoter) shareholders having control of most of these firms. The agency problem in India is also that between a dominant shareholder and minority shareholder. In this paper, we put forward that the proportion of outside director on the board is a determinant of good corporate governance. They are instigated on board because of their high monitoring ability with aimed at reducing the agency cost arising out. Outside directors (non-executive directors), particularly independent directors are mandated by law, in order to protect the minority shareholders, expropriation of firm resources by insiders and to increase firm profitability and its value.

Securities Exchange Board of India (SEBI) first introduced outside directors as a corporate governance mechanism in the Indian corporate regulatory framework in the year 2000. Securities market regulator, SEBI promulgated Clause 49 of the Listing Agreement as corporate governance code for the listed companies. The SEBI endeavor of introducing independent director on the corporate board was to protect the rights of minority shareholders. Clause 49 of the Listing Agreement, in its current form necessitates that where the 
Chairman of the Board is a non-executive director, at least one-third of the Board should comprise of independent directors, and in case he is an executive director ( including non executive promoter chairman), at least half of the Board should comprise of independent directors. In any case, the Board must have at least fifty percent of non-executive directors. Empirical studies in Indian context, Jackling and Johl ( 2009) find a significant positive relationship on firm value (TobinQ) with outside directors, while other studies find no significant relationship between the presence of outside directors on the Board and firm performance (Ghosh, 2006; Kota and Tomar, 2010). However, earlier studies fail to delineate the difference between outside affiliate (grey) directors and outside non-affiliate (independent) directors. We envisage finding the impact of outside directors on firm value and proposing that:

H1: Proportion of non executive directors (independent and grey directors) on the board is positively related to firm value

\section{Effect of Insider Ownership on Outsider Directors Performance in Relation to Firm Value}

Efficacy of outside directors as a corporate mechanism depends upon the bargaining strength of different ownership constituents of a company (Chow and Kim, 2007). Different countries have ownership structure unique to the strength of capital market and legal rights of shareholders. The relative strength of shareholders and their influence depends upon the typical ownership structure. High ownership concentration with a large shareholder controlling the firm is norm of the most of Asian, Latin American and African economies (Shleifer and Vishny, 1986; Shleifer and Vishny, 1997). In Indian context, founding family members or their offspring's, typically known as "Promoters", are generally the largest shareholders in the companies. According to the prowess database of the Center for Monitoring Indian Economy (CMIE), average promoter holding in BSE500 index companies for financial year 2009 is approximately 51.197 percent. Promoters being dominant shareholders in Indian context either occupy a management position or wield significant influence management of the company. Typical agency problems arising out of ownership and control is absent, but a different type of agency cost transpires in Indian companies incited through expropriation of minority shareholder rights by dominant inside shareholders. In companies with dominant shareholders, expropriation of wealth from minority shareholders may come in many ways. Johnson et al., (2000) show that dominant shareholders can divert value by selling assets, goods, or services to the company through self-dealing transactions; they can obtain loans on preferential terms. Bertrand et al., (2002) report a significant amount of tunneling in Indian business groups occurring via non-operating part of the profits. Chakrabarti (2005) further suggests the ownership structure of the Indian companies is very complex with widespread tunneling, cross-holding and pyramiding effect, where promoters acquire ownership rights more than their voting rights. All this helps controlling shareholders to tunnel firm's resources for their private benefits.

The main purpose of outside directors in India is to minimize the agency cost occurring due to ownership concentration and the presence of large inside shareholders. This way, the 
higher is the ownership and control of promoter shareholders (dominant shareholders) on the companies, less will be the effectiveness of outside directors. Controlling rights to promoters allows them, to have direct influence on the appointment of the outside directors on the board. In family controlled firms, outside directors, particularly independent directors, may not be fully committed to their monitoring role, either due impinging authority of promoters or due to their familiarity with them (Chen and Jaggi, 2000; Leblanc and Giles, 2005). Cho and Kim (2007) suggest that the firm performance may deteriorate due to the greater power concentration in the hands of insiders due significant agency cost arising between insiders and minority shareholders. Outside directors, in such context may not act as effective monitors of management due to persistence of high information asymmetry. Choi et al. (2007) in Korean context, suggests that the family ownership concentration negatively affects the board independence and firm performance. Ibrahim and Samad (2011) for Malaysian companies find that the family concentration negatively moderates firm performance. Based on related literature and findings we hypothesize that:

H2: Insider ownership has a negative moderating effect on outside directors' in relation to the firm value

\section{Research Design}

\section{Sample and Data Collection}

The data for research pertains to firms listed on Bombay Stock Exchange (BSE) in the year 2008. Initially, for study BSE 200 firm, which approximately account for 72 percent of market capitalization, were taken. Thereafter, 36 banking and other financial firms were eliminated, as these belong to highly regulated industry. In addition, one firm was left for incomplete financial data. Initial OLS regression was carried out, and six firm observations were found to have undue influence on the model. All these six firm observations were removed from final analysis to keep results robust to outlier's effect. This resulted in a final sample of 157 firms that were taken for empirical validation of different hypothesis proposed. The financial and other data for these firms was obtained from the Prowess database of Centre for Monitoring Indian Economy (CMIE). The data on corporate governance variables like board size, proportion of the outside directors and board leadership for sample firms was extracted from corporate governance reports annexed to annual reports.

\section{Variables}

Market-based measure Tobin's Q has been selected as the dependent variable in this study. It is considered more reliable in India as compliance with accounting standard is weak. Further, market based measure discounts and factors in all parameters affecting firm performance. The explanatory variable in our study is the outside directors (proportion of non-executive directors). Further, we have delineated the difference between affiliate outside directors (gray directors) and non-affiliate outside directors (independent directors) to separately find their effect on firm performance in the main model.

Firm value is not just contingent upon proportion of outside directors on the board, but also influenced by several firm specific factors and other governance parameters. Non-inclusion 
of these parameters may lead spurious relationship between outside directors and firm value. Several firm specific variables like firm age (FAGE), firm size (FSIZE), leverage (LEV) and previous year firm profitability (LAGROA) were included in the regression model as a control variable. Inclusion of these variables as removes heterogeneity related firm and account firm complexity, economies of scale and firm capital structure. Further, corporate governance parameters, like insider ownership (InsOwn), board size (BSIZE) and board leadership (NEDCHAIR) that previous research have suggested that affect the firm performance were also included in the regression model. All variable definitions and measurement are given in Table 1.

Table 1. Variable Definitions and Measurement

\begin{tabular}{|l|l|l|}
\hline Variables & Abbreviation & Measure of Variables \\
\hline TobinQ & TobinQ & $\begin{array}{l}\text { The market value of equity plus the book value } \\
\text { of short-term and long-term debt divided by } \\
\text { total assets }\end{array}$ \\
\hline Outside Directors & PerNE & $\begin{array}{l}\text { Number of non-executive directors divided by } \\
\text { the total number of directors on the board }\end{array}$ \\
\hline $\begin{array}{l}\text { Independent directors } \\
\text { ( Non affiliate outside } \\
\text { directors) }\end{array}$ & PerIND & $\begin{array}{l}\text { Number of independent directors divided by } \\
\text { the total number of directors on the board }\end{array}$ \\
\hline $\begin{array}{l}\text { Grey director ( Affiliate } \\
\text { outside directors) }\end{array}$ & PerGR & $\begin{array}{l}\text { Number of non-executive non-independent } \\
\text { directors divided by the total number of } \\
\text { directors on the board }\end{array}$ \\
\hline Firm Age & FAGE & $\begin{array}{l}\text { Natural logarithm of the number of years } \\
\text { since the establishment of a firm to year } 2009\end{array}$ \\
\hline Firm Size & FSIZE & Natural logarithm of total assets \\
\hline Firm leverage & LAGR & Ratio of long term debt to the total assets \\
\hline $\begin{array}{l}\text { Previous year firm } \\
\text { profitability }\end{array}$ & InsOwn & $\begin{array}{l}\text { Measured as net profit to the total asset } \\
\text { ownership in firm }\end{array}$ \\
\hline Insider ownership & BSIZE & $\begin{array}{l}\text { Total number of directors on the board of } \\
\text { company }\end{array}$ \\
\hline Board size & $\begin{array}{l}\text { A dummy variable, which takes a value of } 1 \text { if } \\
\text { the chairman is non-promoter non-executive } \\
\text { director, else 0 }\end{array}$ \\
\hline Board Leadership & NEDCHAfromoter group \\
\hline
\end{tabular}

\section{Empirical Analysis}

The main aim of research is to validate first hypothesis that the proportion of outside directors (also independent and grey) is positively related to firm performance. We adopted ordinary least squares (OLS) regression to test this hypothesis. Subsequent hypothesis 
required moderating effect of insider ownership on outside directors, and for that purpose moderated regression was adopted.For insider ownership, piecewise moderated regression analysis was performed on outside directors, separately for both independent and gray directors, for the insider ownership level up to fifty percent and above fifty percent. Aim of this type of analysis was to figure out, how does high ownership and absolute control (above 50 percent) to promoters influences outside directors performance in relation to firm value.

\section{Results and Discussions}

The descriptive statistics of the sample companies are presented in Table 2. The average percentage of outside directors (PerNE) is 70.9, and that of independent directors (PerIND) on the board of companies is 50.4 percent. This clearly reflects that the most of boards of companies are comprised of a majority of independent and non-executive directors. The promoter ownership ranges from zero to 100 percent with a mean of 54.5 percent.

Table 2. Descriptive Statistics of Variables

\begin{tabular}{|l|l|l|l|l|l|}
\hline Variables & $\mathrm{N}$ & Minimum & Maximum & Mean & Std. Deviation \\
\hline TOBINQ & 157 & 0 & 4.19 & 1.284 & 0.825 \\
\hline FAGE & 157 & 0.693 & 4.868 & 3.314 & 0.75 \\
\hline FSIZE & 157 & 9.08 & 14.715 & 11.147 & 1.121 \\
\hline LEV & 157 & 0 & 67.96 & 24.25 & 19.095 \\
\hline LAGROA & 157 & -3.99 & 70.96 & 12.171 & 9.989 \\
\hline InSOwn & 157 & 0 & 1 & 0.545 & 0.197 \\
\hline BSIZE & 157 & 5 & 20 & 10.924 & 3.079 \\
\hline NEDCHAIR & 157 & 0 & 1 & 0.159 & 0.367 \\
\hline PerNE & 157 & 0.444 & 1 & 0.709 & 0.132 \\
\hline PerIND & 157 & 0.2 & 0.857 & 0.504 & 0.107 \\
\hline PerGR & 157 & 0 & 0.625 & 0.205 & 0.146 \\
\hline
\end{tabular}

Table 3 illustrates the correlations among different explanatory, control and dependent variables that have used in the regression analysis. As shown in Table 3, an interesting finding from the correlation matrix is that promoter ownership is positively related to firm size, contemplating the fact that most of the large firms in India are promoted dominated and belongs to family managed group. Correlation Matrix reflects a significant correlation between an outside director (PerNE), gray director (PerGR) and independent director (PerIND). High correlation is quite evident from the fact that all these are endogenous in board composition. However, multicolinearity is within permissible limit (0.709) and further, as we entered all these categories of outside directors independently in the regression model, multicollinearity was not an issue. The highest variance inflation factor (VIF) in the regression model (without interaction terms) was easily within the limit. However, we do the faced issue of multicollinearity, when interaction terms for testing moderation effect were 
entered in the regression model. Therefore, in order to remove multicollinearity, all the variables whose interaction effect to be analyzed in the regression model were mean centered. Thereafter, multicollinearity was not a significant issue in the regression analyses, as none of VIF approached the critical value of 10 . Other criteria for checking the multicollinearity is condition index, which in all regression models was always with the maximum permissible limit of 50 , for the social science research.

Table 3. Pearson Correlation Matrix between Variables

\begin{tabular}{|c|c|c|c|c|c|c|c|c|c|c|}
\hline & TOBINQ & PerNE & PerIND & PerGR & BSIZE & NEDCHAIR & FAGE & FSIZE & LEV & LAGROA \\
\hline PerNE & -.085 & & & & & & & & & \\
\hline PerIND & -.023 & $.265^{* *}$ & & & & & & & & \\
\hline PerGR & -.060 & $.709 * *$ & $-.493 * *$ & & & & & & & \\
\hline BSIZE & -.072 & -.136 & $-.195 *$ & .020 & & & & & & \\
\hline NEDCHAIR & .135 & .090 & $-.179 *$ & $.212 * *$ & -.097 & & & & & \\
\hline FAGE & -.154 & $-.169 *$ & -.120 & -.065 & .125 & -.035 & & & & \\
\hline FSIZE & $-.235^{* *}$ & -.149 & -.022 & -.118 & $.309 * *$ & $-.194 *$ & $.178^{*}$ & & & \\
\hline LEV & $-.311 * *$ & -.106 & .118 & $-.181 *$ & -.004 & -.057 & -.053 & .102 & & \\
\hline LAGROA & $.365^{* *}$ & -.097 & -.021 & -.071 & -.062 & .024 & .044 & -.098 & $-.360 * *$ & \\
\hline InsOwn & .140 & -.046 & -.052 & -.004 & -.016 & -.038 & -.042 & $.205^{* *}$ & $-.213 * *$ & .053 \\
\hline
\end{tabular}

The regression results are presented in Table 4 and 5. The results are robust to the effect of multi-collinearity, outliers and non-linearity. Squared terms of PerNE, PerIND and PERGR were also included in the regression equation and no significant difference was found. The results of this regression model are not shown here. Further, randomly 100 firms were selected for regression. The regression results were robust to that with no significant difference observed from main findings. The Table 4 presents regression analysis performed to examine the impact of outside directors on the firm value. There is a significant negative relationship between the outside directors (without delineating the difference between grey and independent directors) and the firm value, which rejects hypothesis 1 ( $\mathrm{r}=-0.852, \mathrm{p}<0.1$ ). When grey (affiliate outside directors) and independent director (non-affiliate outside directors) were differentiated, there clear was a clear demarcation in the firm performance. The percentage of the grey director on board has a significant negative relationship $(r=-0.749$, $\mathrm{p}<0.1$ ) with firm value, while independent directors do not have significant positive impact on firm value. Promoters ownership is positively related to firm value in all models as investigated in many prior studies studied (Khanna and Palepu, 1999; Singh and Gaur, 2009). The results are consistent with other Asian Countries and Indian studies (Chow and Kim, 2007; Ghosh, 2006; Kota and Tomar, 2010) which have also not find any significant association with the presence of outside directors on the board. As some evidence of 
regression results of Table 4, that the grey directors mainly drive the negative impact of outside director on the value, offsetting the positive influence of independent directors.

Table 4. Tobin’s Q- Board composition by outside directors

\begin{tabular}{|c|c|c|c|c|c|c|}
\hline \multirow[b]{2}{*}{ Independent variables } & \multicolumn{2}{|c|}{ NE Director } & \multicolumn{2}{|c|}{ Grey Director } & \multicolumn{2}{|c|}{ IND Director } \\
\hline & coeff & $P$ value & coeff & $P$ value & coeff & P value \\
\hline (Constant) & 3.631 & 4.593* & 3.066 & $4.647 *$ & 2.726 & $3.692 *$ \\
\hline PERNE & -0.0852 & $-1.837 * * *$ & & & & \\
\hline PERGR & & & -0.749 & $-1.772 * * *$ & & \\
\hline PERIND & & & & & 0.79 & 0.136 \\
\hline BSIZE & 0.004 & 0.196 & 0.01 & 0.489 & 0.008 & 0.402 \\
\hline NEDCHAIR & 0.209 & 1.29 & 0.25 & 1.512 & 0.197 & 1.181 \\
\hline FAGE & -0.173 & $-2.152 * *$ & -0.16 & $-1.999 * *$ & -0.15 & $-1.852 * * *$ \\
\hline FSIZE & -0.142 & $-2.421 * *$ & -0.143 & $-2.435 * *$ & -0.135 & $-2.293 * *$ \\
\hline LEV & -0.08 & $-2.385 * *$ & -0.008 & $-2.436 * *$ & 0.007 & $-2.091 * *$ \\
\hline LAGROA & -0.022 & $-3.431 *$ & 0.022 & $3.456 *$ & 0.024 & $3.726 *$ \\
\hline INSOWN & 0.487 & 1.551 & 0.513 & $1.637 * * *$ & 0.524 & $1.664^{* * *}$ \\
\hline No. of Firms & \multicolumn{2}{|c|}{157} & \multicolumn{2}{|r|}{157} & \multicolumn{2}{|r|}{157} \\
\hline Adj R square & \multicolumn{2}{|c|}{0.224} & \multicolumn{2}{|r|}{0.223} & \multicolumn{2}{|r|}{0.207} \\
\hline F change & \multicolumn{2}{|c|}{6.639} & \multicolumn{2}{|r|}{6.6} & \multicolumn{2}{|r|}{6.052} \\
\hline
\end{tabular}

The results does not hypothesis 2. In fact, it is rejected that insider ownership has a negative moderating effect on outside director's performance. The empirical findings of moderated regression model show very weak but positive moderating effect of promoter ownership on outside directors (Table 5). On further examination, it may find that moderating effect of insider ownership is positive on grey directors but negative on independent directors. The results here may be explained and interpreted in several ways.

There is weak but positive moderating effect of insider control on performance of outside grey directors. This is due to the alignment of incentives of grey directors with greater ownership by insiders. Grey directors being affiliated with ownership have interests aligned with managers cum owners (promoters) and perform their advising role to good extent in devising firm strategy. This leads to a positive impact on firm value. The high ownership eliminates the typical agency problem arising from the separation of ownership and control and has a positive effect on firm value. This is evident from positive (in some models significant) association with promoter ownership with firm value in all the models and 
consistent with prior studies (Khanna and Palepu, 1999; Singh and Gaur, 2009). However, this actuates high agency cost in terms of monitoring by independent directors in safeguarding minority shareholder rights. In a high informatory asymmetry environment with presence of greater ownership of promoters outside directors, both monitoring and advisory role is less efficacious (Duchin et al., 2010). Our findings are consistent with Chow and Kim (2007) findings, and their explanation of substitute governance mechanisms (Redikar and Seth, 1995) is also valid in Indian context. The ownership concentration among a dominant shareholder (promoter) minimizes the risk of takeover, and therefore acts substitute mechanism for monitoring by independent directors. A higher proportion of independent with high insider ownership further attenuates conflict of interest between them and the management / owner that may hinder the decisions making process (Singh and Gaur, 2009). Another perspective for explanation is ownership and control by promoters on firm allows them to have their own people on the board as an independent director. In such cases, the independent director role is more or less ceremonial and only for compliance requirement purpose. 
Table 5. TobinQ- Moderating effect of insider ownership on outside director

\begin{tabular}{|c|c|c|c|c|c|c|}
\hline \multirow[b]{2}{*}{ Independent Variables } & \multicolumn{2}{|c|}{ NE Director } & \multicolumn{2}{|c|}{ Independent Director } & \multicolumn{2}{|c|}{ Grey Director } \\
\hline & coeff & $\mathrm{P}$ value & coeff & $\mathrm{P}$ value & coeff & $\mathrm{P}$ value \\
\hline (Constant) & 3.532 & 4.35 & 2.738 & 3.688* & 2.96 & 4.441 \\
\hline \multirow[t]{2}{*}{ INSOWN0-50* (PERNE,PERIND,PERGR) } & & & & & & \\
\hline & 1.328 & 0.266 & -1.798 & -0.374 & 2.759 & 0.642 \\
\hline \multicolumn{7}{|l|}{ INSOWN51-100* } \\
\hline (PERNE,PERIND,PERGR) & 1.412 & 0.482 & -2.007 & -0.537 & 2.662 & 1.08 \\
\hline PERNE & -0.829 & $-1.769 * * *$ & & & & \\
\hline PERIND & & & 0.08 & 0.137 & & \\
\hline PERGR & & & & & -0.78 & $-1.827^{* * *}$ \\
\hline BSIZE & 0.005 & 0.24 & 0.009 & 0.411 & 0.012 & 0.591 \\
\hline NEDCHAIR & 0.213 & 1.303 & 0.185 & 1.095 & 0.248 & 1.486 \\
\hline FAGE & -0.169 & $-2.059 * *$ & -0.156 & $-1.897 * * *$ & -0.161 & $-2.006^{* *}$ \\
\hline FSIZE & -0.138 & $-2.330 * *$ & -0.136 & $-2.286 * *$ & -0.138 & $-2.336 * *$ \\
\hline LEV & -0.008 & $-2.330 * *$ & -0.007 & $-2.018^{* *}$ & -0.008 & $-2.328 * *$ \\
\hline LAGROA & 0.022 & $3.459 *$ & 0.023 & $3.668^{*}$ & 0.022 & $3.505^{*}$ \\
\hline INSOWN & 0.505 & 1.579 & 0.541 & $1.694^{* * *}$ & 0.564 & $1.77^{* * *}$ \\
\hline No. of Firms & \multicolumn{2}{|r|}{157} & \multicolumn{2}{|r|}{157} & \multicolumn{2}{|r|}{157} \\
\hline $\mathrm{R}$ & \multicolumn{2}{|c|}{0.516} & \multicolumn{2}{|r|}{0.515} & \multicolumn{2}{|c|}{0.515} \\
\hline R square & \multicolumn{2}{|c|}{0.266} & \multicolumn{2}{|c|}{0.265} & \multicolumn{2}{|c|}{0.265} \\
\hline Adj R square & \multicolumn{2}{|c|}{0.216} & \multicolumn{2}{|r|}{0.22} & \multicolumn{2}{|r|}{0.22} \\
\hline F change & \multicolumn{2}{|r|}{5.296} & \multicolumn{2}{|r|}{5.88} & \multicolumn{2}{|r|}{5.88} \\
\hline
\end{tabular}

\section{Conclusions}

This paper modestly examines efficacy of outside directors as an important corporate governance mechanism, from an agency perspective in both developed and emerging countries, also covering the extant literature that divulges their impact on the firm performance. Emerging markets that are steadily integrating with the global economy are getting high recognition in corporate governance study (Chow and Kim, 2007). Corporate boards with outside independent directors are considered as an important internal corporate mechanism in the absence of external governance mechanisms in emerging markets (Singh and Gaur, 2009). This paper investigates the importance of outside directors on corporate 
boards of Indian companies and their influence on firm value. It further examines the moderating effect of dominant shareholder on outside directors in relations to firm value. Analysis of outside directors as determinant of firm performance is also carried out by delineating the difference between grey and independent directors. This aspect has been often lacking in previous studies.

This study finds that the negative effect of outside directors on the firm value of Indian companies is mainly due to the grey directors, where as independent directors have a positive but insignificant effect. It may be concluded that market values companies with a greater proportion of independent directors. However, the promoters who are owners and controllers of Indian companies negatively impact the performance of independent directors. The results have some implications for policy makers who are trying to find a suitable board model for companies and define the role of independent directors. The study implicates that for an independent board with grey directors to be replaced by an independent director. Further, a greater discussion and analysis is required so that independent directors remain independent of the promoters and able to safeguard minority shareholder rights. Reforms are required that may confiscate promoters control on independent director's selection and appointment process.

\section{References}

Agrawal, A., \& Knoeber, C. (1996). Firm performance and mechanisms to control Agency problems between managers and shareholders. Journal of Financial Quantitative Analysis, 31(3), 377-397. http://dx.doi.org/10.2307/2331397

Ameer, R., Ramli, F., \& Zakaria, H. ( 2011). A new perspective on board composition and firm performance in an emerging market. Corporate Governance, 10(5), 647-661.

Bathala, C., \& Rao, R. ( 1995). The determinants of board composition: an agency theory perspective. Managerial and Decision Economics, 16(1), 59-69. http://dx.doi.org/10.1002/mde.4090160108

Baysinger, B., \& Butler, H. (1985). Corporate governance and the board of directors: performance effects of changes in board composition. Journal of Law, Economics, \& Organization, 1(1), 101-124.

Beasley, M.S. (1996). An empirical analysis of the relation between the board of director composition and financial statement fraud. The Accounting Review, 71, 443-65.

Bertrand, M., Mehta, P., \& Mullainathan, S. (2002). Ferreting out tunneling: An application to Indian business groups. Quarterly Journal of Economics, 117, 121-148. http://dx.doi.org/10.1162/003355302753399463

Bhagat, S., \& Black, B. (2002). The non-correlation between board independence and long-term firm performance. Journal of Corporation Law, 27(2), 231-273. 
Brennan, N. (2006). Board of directors and firm performance: is there an expectation gap? Corporate Governance: An International Review, 14(6), 577-593. http://dx.doi.org/10.1111/j.1467-8683.2006.00534.x

Brickley, J., Coles, L., \& Terry, R. (1994). Outside directors and the adoption of poison pills. Journal of Financial Economics, 35, 390. http://dx.doi.org/10.1016/0304-405X(94)90038-8

Byrd, J., \& Hickman, K. (1992). Do outside directors monitor managers? Journal of Financial Economics, 32, 195-221. http://dx.doi.org/10.1016/0304-405X(92)90018-S

Chakrabarti, R. (2005). Corporate governance in India: evolution and challenges. The ICFAI Journal of Corporate Governance, 4(4), 50-68.

Chen, C.J.P., \& Jaggi, B. (2000). Association between independent directors, family control and financial disclosures in Hong Kong. Journal of Accounting and Public Policy, 19(4/5), 285-310. http://dx.doi.org/10.1016/S0278-4254(00)00015-6

Cho, D.S., \& Kim, J. (2007). Outside directors, ownership structure and firm profitability in Korea. Corporate Governance: An International Review, 15(2), 239-250. http://dx.doi.org/10.1111/j.1467-8683.2007.00557.x

Choi, J.J., Park, S.E., \& Yoo, S.S. (2007). The outside directors in Korea: evidence from corporate governance reform in Korea. Journal of Financial and Quantitative Analysis, 42(4), 941-962. http://dx.doi.org/10.1017/S0022109000003458

Claessens, S., Djankov, S., \& Lang, L. (2000). The separation of ownership and control in East Asian corporations. Journal of Financial Economics, 58, 81-112. http://dx.doi.org/10.1016/S0304-405X(00)00067-2

Claessens, S., Djankov, S., Fan, J.P.H., \& Lang, L. (2002). Distangling the incentive and entrenchment of large shareholdings. The Journal of Finance, 57(6), 2741-2771. http://dx.doi.org/10.1111/1540-6261.00511

Core, J.E., Holthausen, R.W., \& Larcker, D.F. (1999). Corporate governance, chief executive officer and firm performance. Journal of Financial Economics, 51, 371-406. http://dx.doi.org/10.1016/S0304-405X(98)00058-0

Dahya, J.,Dimitrov, O., \& McConnell, J. (2006). Dominant shareholders, corporate boards and corporate value: a cross-country analysis. Journal of Financial Economics, 87, 73-100. http://dx.doi.org/10.1016/j.jfineco.2006.10.005

Dalton, D, Daily, C., Ellstrand, A., \& Johnson, J. (1998). Meta-analytic reviews of board composition, leadership structure, and financial performance. Strategic Management Journal, 19

269-290.

http://dx.doi.org/10.1002/(SICI)1097-0266(199803)19:3<269::AID-SMJ950>3.0.CO;2-K

Dalton, D. R., \& Daily, C. M. (1999). What's wrong with having friends on the board. Across the Board, 36(3), 28-32. 
Denis, D.J., \& Sarin, A. (1999). Ownership and board structures in publicly traded companies. $\begin{array}{llr}\text { Journal of Financial } & \text { Economics, } & \text { 52(2), }\end{array}$ http://dx.doi.org/10.1016/S0304-405X(99)00008-2

Duchin, R., Matsusaka, J.G., \& Ozbas, O. (2010). When are outside directors effective? Journal of Financial Economics, 96(2), 195-214. http://dx.doi.org/10.1016/j.jfineco.2009.12.004

Ehikioya, B. I. (2009). Corporate governance structure and firm performance in developing economies: evidence from Nigeria. Corporate Governance, 9 (3), 231-243 http://dx.doi.org/10.1108/14720700910964307

Erickson, J., Park, Y. W., Resing, J., \& Shin, H.H. (2005). Board composition and firm value under concentrated ownership: the Canadian evidence. Pacific- Basin Finance Journal, 13, 387-410. http://dx.doi.org/10.1016/j.pacfin.2004.11.002

Ezzamel, M.A., \& Watson, R. (1993). Organisational form, ownership structure and corporate performance: A contextual empirical analysis of UK companies. British Journal of Management, 4, 161-176. http://dx.doi.org/10.1111/j.1467-8551.1993.tb00056.x

Fama, E., \& Jensen, M. (1983). Separation of ownership and control. Journal of Law and Economics, 26, 301-325. http://dx.doi.org/10.1086/467037

Fernandes, N. (2005). Board compensation and firm performance: the role of "independent" board members. ECGI Working Paper Series in Finance, European Corporate Governance Institute.

Ghosh, S. (2006). Do board characteristics affect corporate performance? Firm-level evidence for India. Applied Economics Letters, 13(7), 435-443. http://dx.doi.org/10.1080/13504850500398617

Hermalin, B.E., \& Weisbach, M.S. (1991). The effect of board composition and direct incentives in firm performance. Financial Management, 20(4), 101-12. http://dx.doi.org/10.2307/3665716

Hillman, A.J., \& Dalziel, T. (2003). Boards of directors and firm performance: integrating agency and resource dependence perspectives. The Academy of Management Review, 28(3), 383-396.

Ibrahim, H., \& Samad, F.A. (2011). Corporate governance mechanisms and performance of public-listed family-ownership in Malaysia. International Journal of Economics and Finance, 3(1), 105-115.

Jackling, B., \& Johl, S. (2009). Board structure and firm performance: evidence from India’s top companies. Corporate Governance: An International Review, 17(4), 492-509. http://dx.doi.org/10.1111/j.1467-8683.2009.00760.x 
Jensen, M., \& Meckling, W. (1976). Theory of the firm: managerial behaviour, agency cost and ownership structure. Journal of Financial Economics, 3, 305-350. http://dx.doi.org/10.1016/0304-405X(76)90026-X

Johnson, S., Boone, P., Breach, A., \& Friedman, E. (2000). Corporate governance in the Asian financial crisis. Journal of Financial Economics, 58, 141-186. http://dx.doi.org/10.1016/S0304-405X(00)00069-6

Khanna, T., \& Palepu, K. (1999). Emerging market business groups, foreign investors and corporate governance. NBER Working Paper Series No 6955, 1-33.

Kota, H.M., \& Tomar, C. (2010). Corporate governance practices of Indian firms. Journal of Management and Organisation, 16, 266-279. http://dx.doi.org/10.5172/jmo.16.2.266

La Porta, R, Lopez-de-silanes, F, Shleifer, A and Vishny, R. (2002). Investor protection and corporate valuation. Journal of Finance. 57(3), 1147-1170. http://dx.doi.org/10.1111/1540-6261.00457

La Porta, R., Lopez-de-Silanes, F, Shleifer, A., \& Vishny, R. (2000). Investor protection and corporate governance. Journal of Financial Economics, 58, 3-27. http://dx.doi.org/10.1016/S0304-405X(00)00065-9

McCabe, M., \& Nowark, M. (2008). The independent directors on the board of company. Managerial Auditing Journal, 23(6), 545-566. http://dx.doi.org/10.1108/02686900810882101

Mehran, H. (1995). Executive compensation structure, ownership, and firm performance. $\begin{array}{llllll}\text { Journal of Financial } & \text { Economics, } & 38, & 163- & \end{array}$ http://dx.doi.org/10.1016/0304-405X(94)00809-F

Rashid, A., De Zoysa, A., Lodh, S., \& Rudkin, K. (2010). Board composition and firm performance: evidence from Bangladesh. Australasian Accounting Business and Finance Journal, 4(1), 76-95.

Rediker, K., \& Seth, A (1995). Boards of directors and substitution effects of alternative governance mechanism. Strategic Management Journal, 16, 85-100. http://dx.doi.org/10.1002/smj.4250160202

Rhoades, D., Rechner, P., \& Sundaramurthy, C. (2000). Board composition and financial performance: a meta-analysis of the influence of outside directors. Journal of Managerial Issues, 12(1), 76-91.

Rosenstein, S., \& Wyatt, J. G. (1990). Outside directors, board independence and shareholders wealth. Journal of Financial Economics, 26(2), 175-191. http://dx.doi.org/10.1016/0304-405X(90)90002-H

Ruigrok, W., Peck, S., \& Keller, P. (2006). Board characteristics and involvement in strategic decision making: evidence from Swiss companies. Journal of Management Studies, 43(5), 1201-1226. http://dx.doi.org/10.1111/j.1467-6486.2006.00634.x 


\section{Macrothink}

Asian Journal of Finance \& Accounting

ISSN 1946-052X

2012, Vol. 4, No. 2

Shleifer, A., \& Vishny, R. W. (1986). Large shareholders and corporate control. Journal of Political Economics, 94(3), 461-488. http://dx.doi.org/10.1086/261385

Shleifer, A., \& Vishny, R.W. (1997). A survey of corporate governance. Journal of Finance, 52(2), 737-783.

Singh J.P., Kumar, N., \& Uzma, S. (2010). Satyam fiasco: corporate governance failure and lessons therefrom. ICFAI Journal of Corporate Governance, 9(4), 30-39.

Tellis, O (2009). Whiter Justice for Satyam Investors? Deccan Chronicle, December 02.

Uadiale, O.M. (2010). The impact of board structure on corporate financial performance in Nigeria. International Journal of Business and Management, 5(10), 155-166.

Vafeas, N., \& Theodorou, E. (1998). The relationship between board structure and Firm performance in UK. The British Accounting Review, 30(4), 383-407. http://dx.doi.org/10.1006/bare.1998.0075

Weisbach, M. (1988). Outside directors and CEO turnover. Journal of Financial Economics, 20(1), 431-460. http://dx.doi.org/10.1016/0304-405X(88)90053-0

Xie, B., Davidson III, W.N., \& DaDalt, P.J. ( 2003). Earnings management and corporate governance: The role of the board and the audit committee. Journal of Corporate Finance, 9, 295- 316. http://dx.doi.org/10.1016/S0929-1199(02)00006-8

Yammeesri, J., \& Herath, S.K. (2010). Board characteristics and corporate value: evidence from Thailand. Corporate Governance, 10(3), 279-292. http://dx.doi.org/10.1108/14720701011051910

Yermack, D. (1996). Higher market valuations of companies with a small board of directors. $\begin{array}{lllll}\text { Journal of Financial } & \text { Economics, } & \text { 40, }\end{array}$ http://dx.doi.org/10.1016/0304-405X(95)00844-5 